\title{
Calcium isotopic compositions of arc magmas: the absence of subduction signal
}

\author{
JiN-TING KANG ${ }^{1}$, YU-HAN QI ${ }^{1}$, HUI-MIN YU ${ }^{1}$, ZHAO-
} FENG ZHANG $^{2}$, AND FANG HUANG ${ }^{1}$

${ }^{1}$ School of Earth and Space Sciences, University of Science and Technology of China, Hefei 230026, China

${ }^{2}$ State Key Laboratory of Isotope Geochemistry, Guangzhou Institute of Geochemistry, Guangzhou 510640, China

To investigate the effect of subduction components on the $\mathrm{Ca}$ isotopic budget of mantle wedge, we measured $\mathrm{Ca}$ isotopic composition of 36 well-characterized arc magmas from Southern Lesser Antilles, Central-Eastern Aleutian and Central America arc. These rocks show typical arc characteristics with high LILE and fluid-mobile elements content and enriched $\mathrm{Sr}-\mathrm{Nd}-\mathrm{Pb}$ isotope compositions, suggesting the contributions of fluids/melts derived from subduction slab.

$\delta^{44 / 40} \mathrm{Ca}$ of these rocks show an average value of $0.82 \pm 0.12 \%$ o (2SD, $\mathrm{n}=36)$ ranged from $0.70 \pm 0.14$ to $1.00 \pm 0.02 \%$, which are lighter than that of $\mathrm{BSE}^{[1]}$ $(0.94 \pm 0.05 \%)$ and comparable to the reported values of fresh MORB $(0.83 \pm 0.11 \%)^{[2,3]}$ and BABBs $(0.80 \pm 0.08 \%$, $\mathrm{n}=21)^{[4]}$. The $\delta^{44} \mathrm{Ca}$ in our investigated rocks shouldn't be modified by post-magmatic process because they show no correlations with CIA and $\mathrm{Rb} / \mathrm{TiO}_{2}$. Also, correlations were not observed between $\delta^{44 / 40} \mathrm{Ca}$ and $\mathrm{CaO}, \mathrm{MgO}, \mathrm{Sr} / \mathrm{Nd}$ and $\mathrm{Eu} / \mathrm{Eu}^{*}$, indicating limited or insignificant $\mathrm{Ca}$ isotope fractionation induced by clinopyroxene, plagioclase and amphibole fractional crystallization. In fact, even though the mantle source of arc magmas investigated here were strongly affected by materials derived from subduction sediments or altered oceanic crust either in the form of fluids or melts, we observed no systematic variations of $\delta^{44} \mathrm{Ca}$ with $\mathrm{Ba} / \mathrm{La}, \mathrm{Ba} / \mathrm{Th}$, $\mathrm{Sr} / \mathrm{Y}, \mathrm{Hf} / \mathrm{Lu}$ and ${ }^{87} \mathrm{Sr} /{ }^{86} \mathrm{Sr}$. The absence of subduction signals in $\mathrm{Ca}$ isotope compositions of arc magmas may reflect: (1) low $\mathrm{CaO}$ content in subduction sediments, (2) incongruent releasing of $\mathrm{Ca}^{2+}$ and $\mathrm{CO}_{3}{ }^{2-}$ during carbonate breakdown in the sub-arc region, (3) a "mantle chromatograph" which attenuates the $\mathrm{Ca}$ isotope signal during slab fluids/melts ascent through the mantle wedge.

[1] Kang et al (2017) EPSL 474 128-137 [2] Zhu et al (2018) JGR SE 123 1303-1313 [3] Chen et al. (2019) GCA [4] Zhu et al. (2020) GCA 2020 379-393 